\title{
Acute myeloid leukemia fusion proteins deregulate genes involved in stem cell maintenance and DNA repair
}

\author{
Myriam Alcalay, ${ }^{1,2}$ Natalia Meani, ${ }^{1,2}$ Vania Gelmetti, ${ }^{1,2}$ Anna Fantozzi, ${ }^{1,2}$ Marta Fagioli, ${ }^{3}$ \\ Annette Orleth, ${ }^{3}$ Daniela Riganelli, ${ }^{3}$ Carla Sebastiani, ${ }^{3}$ Enrico Cappelli, ${ }^{4}$ Cristina Casciari, ${ }^{3}$ \\ Maria Teresa Sciurpi, ${ }^{3}$ Angela Rosa Mariano, ${ }^{3}$ Simone Paolo Minardi, ${ }^{2}$ Lucilla Luzi, ${ }^{1,2}$ \\ Heiko Muller, ${ }^{1,2}$ Pier Paolo Di Fiore, ${ }^{1,2}$ Guido Frosina, ${ }^{4}$ and Pier Giuseppe Pelicci,, 2
}

\begin{abstract}
${ }^{1}$ Department of Experimental Oncology, European Institute of Oncology, Milan, Italy ${ }^{2}$ IFOM - Institute of Molecular Oncology of the Italian Foundation for Cancer Research, Milan, Italy ${ }^{3}$ Department of Clinical and Experimental Medicine, Università degli Studi di Perugia, Policlinico Monteluce, Perugia, Italy ${ }^{4}$ DNA Repair Unit, Mutagenesis Laboratory, Istituto Nazionale Ricerca Cancro, Genoa, Italy
\end{abstract}

Acute myelogenous leukemias (AMLs) are genetically heterogeneous and characterized by chromo-
somal rearrangements that produce fusion proteins with aberrant transcriptional regulatory activi-
ties. Expression of AML fusion proteins in transgenic mice increases the risk of myeloid leukemias,
suggesting that they induce a preleukemic state. The underlying molecular and biological mecha-
nisms are, however, unknown. To address this issue, we performed a systematic analysis of fusion
protein transcriptional targets. We expressed AML1/ETO, PML/RAR, and PLZF/RAR in U937 hemo-
poietic precursor cells and measured global gene expression using oligonucleotide chips. We identi-
fied 1,555 genes regulated concordantly by at least two fusion proteins that were further validated in
patient samples and finally classified according to available functional information. Strikingly, we
found that AML fusion proteins induce genes involved in the maintenance of the stem cell pheno-
type and repress DNA repair genes, mainly of the base excision repair pathway. Functional studies
confirmed that ectopic expression of fusion proteins constitutively activates pathways leading to
increased stem cell renewal (e.g., the Jagged1/Notch pathway) and provokes accumulation of DNA
damage. We propose that expansion of the stem cell compartment and induction of a mutator phe-
notype are relevant features underlying the leukemic potential of AML-associated fusion proteins.
$\mathrm{J}$. Clin. Invest. 112:1751-1761 (2003). doi:10.1172/JCI200317595.

\section{Introduction}

The pathogenesis of acute myeloid leukemias (AMLs) is linked to oncogenic fusion proteins, generated as a consequence of primary chromosome translocations or inversions (1). Many different types of translocations have been described in AMLs, the most frequent being the $\mathrm{t}(8 ; 21), \mathrm{t}(15 ; 17)$, inv(16), and $\mathrm{t}(9 ; 11)$, which, taken together with their variants, account for approximately $40 \%$ of AML cases (2).

Despite genetic heterogeneity, there is increasing evidence for common molecular and biological mechanisms in AMLs. In particular, one of the components of each fusion protein is invariably a transcription factor, frequently involved in the regulation of differentiation (3). As a consequence, AML-associated fusion

Received for publication December 11, 2002, and accepted in revised form August 5, 2003.

Address correspondence to: Myriam Alcalay, IFOM, Via Adamello 16, 20139 Milano, Italy. Phone: 39-02-574303226; Fax: 39-02-574303231; E-mail: alcalay@ifom-firc.it.

Conflict of interest: The authors have declared that no conflict of interest exists.

Nonstandard abbreviations used: acute myeloid leukemias (AMLs); hemopoietic stem cell (HSC); U937 cells transfected with empty PSG-MtNEO vector (Mt); retinoic acid (RA); retinoic acid receptor $\alpha[$ RAR $\alpha]$ Microarray Suite v.5 (MASv5); cycle threshold $\left(C_{T}\right)$; intracellular domain of Notch (ICD Notch); methyl methanesulfonate (MMS); base excision repair (BER). proteins function as aberrant transcriptional regulators with the potential to interfere with the processes of myeloid differentiation. Indeed, ectopic expression of different fusion proteins into hemopoietic precursors induces a state of partial refractoriness to terminal differentiation and increases cell survival (4-6). It has been suggested, therefore, that AML-associated fusion proteins contribute to the leukemic phenotype by inducing a differentiation block: a biological activity consistent with the main phenotypic trait of AMLs (i.e., the accumulation of hemopoietic precursors blocked at particular stages of myeloid development).

Analysis of mice transgenic for various fusion proteins revealed, however, a more complex scenario. Transgenic mice develop leukemias after long latency, suggesting that while AML-associated fusion proteins induce a preleukemic state, other genetic events are necessary for progression to a frank leukemia (7-9). It is unclear whether fusion proteins also induce a mutator phenotype, thereby favoring accumulation of further genetic alterations. In the preleukemic state, the myeloid compartment of the transgenic animals appears morphologically normal, and the only detectable abnormalities are an increase in the self-renewal capacity of hemopoietic progenitors and minor alterations of differentiation markers (8-10). This suggests that the effect of AMLassociated fusion proteins on the differentiation program 
cannot be explained solely by their ability to block differentiation. Thus, further investigations are needed to characterize the biological contribution of AML-associated fusion proteins to the leukemogenic process in vivo.

A powerful approach to identify novel biological activities of AML fusion proteins is the characterization of their transcriptional targets through microarray analyses of patient samples. Analysis of blast samples with $\mathrm{t}(8 ; 21), \mathrm{t}(15 ; 17)$, and inv(16) has revealed a unique correlation between AML-specific cytogenetic aberrations and gene expression profiles (11). Genes that are coregulated by different AML fusion proteins would not be identified by these studies, however, which are based on cluster analysis of different AML samples. To investigate common pathogenetic mechanisms in AMLs, we expressed different fusion proteins (AML1/ETO, which represents a fusion of the Acute Myeloid Leukemia 1 and the Eight-Twenty One gene products and is generated by the 8;21 translocation; PML/RAR, a fusion of the Promyelocytic Leukemia and the Retinoic Acid Receptor $\alpha[$ RAR $\alpha]$ gene products, generated by the $15 ; 17$ translocation; and PLZF/RAR, a fusion of the Promyelocytic Leukemia Zinc Finger and the RAR $\alpha$ gene products, generated by the 11;17 translocation) in the same genetic background and measured global gene expression using oligonucleotide chips. These experiments showed that a relevant number of regulated genes are targets of more than one AML fusion protein. Functional clustering revealed that AML fusion proteins influence the activity of genes involved in the control of diverse functions, including differentiation, cell survival, DNA repair, signal transduction, and several metabolic pathways. We further demonstrated that expression of AML fusion proteins activates Notch signaling through overexpression of the Jagged 1 ligand, a function known to favor expansion of the hemopoietic stem cell (HSC) compartment. We also show that AML fusion protein expression can inhibit DNA repair function, suggesting that an increase in the rate of secondary mutations is a direct consequence of fusion protein expression.

\section{Methods}

Cell lines and samples. The U937 PML/RAR\#9, U937 AML1/ETO-HA\#9, and U937 PLZF/RAR\#3 clones were generated by stable transfection of U937 cells with the corresponding cDNAs cloned in the pSG-MtNEO plasmid vector; single clones were selected with $750 \mu \mathrm{M}$ G418 for 15 days. A bulk population of U937 cells transfected with the empty pSG-MtNEO vector $(\mathrm{Mt})$ was used as the control. Unless specified otherwise, U937 cells lines were treated for 8 hours with $100 \mu \mathrm{M}$ $\mathrm{ZnSO}_{4}$ to allow expression of fusion proteins. These particular clones were chosen because they presented comparable levels of protein expression after induction. AML blasts and all cell lines were maintained in RPMI1640 supplemented with $50 \mathrm{U} / \mathrm{ml}$ penicillin, $50 \mu \mathrm{g} / \mathrm{ml}$ streptomycin, and $10 \% \mathrm{FCS}$ at $37^{\circ} \mathrm{C}$ in a humidified atmosphere containing 5\% $\mathrm{CO}_{2}$. AML blasts and $\mathrm{U} 937$ $\mathrm{PML} / \mathrm{RAR}$ were treated with $10^{-6} \mathrm{M}$ retinoic acid (RA)
(Sigma-Aldrich, St. Louis, Missouri, USA) for 4 and 12 hours prior to RNA extraction, as indicated.

RNA extraction. Total RNA was extracted using TRIzol reagent (Invitrogen, Carlsbad, California, USA) method, followed by clean up on RNeasy Mini/Midi Kit (QIAGEN, Valencia, California, USA). For each of the four U937 cell lines (PML/RAR, AML1/ETO, PLZF/RAR, and $\mathrm{Mt}$ ), three independent vials were thawed, and the $\mathrm{ZnSO}_{4}$ inductions and RNA extractions were performed separately. An equal quantity of each of the three RNA preparations was then mixed to generate an RNA pool for each sample. Total RNA was extracted from CD34 ${ }^{+}$ hemopoietic precursor cells (from healthy donors) purified using standard procedures and from AML blasts bearing $\mathrm{t}(15 ; 17)$ or $\mathrm{t}(8 ; 21)$ derived from Ficoll-purified bone marrow samples with more than $80 \%$ of the blasts collected at disease onset (prior to any therapy).

Affymetrix GeneChip bybridization. Biotin-labeled cRNA targets were obtained starting from $10 \mu \mathrm{g}$ of total RNA derived from a pool of three different RNA extractions for each condition. cDNA synthesis was performed with a Gibco SuperScript Custom cDNA Synthesis Kit, and biotin-labeled antisense RNA was transcribed in vitro using the In Vitro Transcription System (Ambion Inc., Austin, Texas, USA) and included Bio-16-UTP and Bio11-CTP (Enzo Life Sciences Inc., Farmingdale, New York, USA) in the reaction. GeneChip hybridization, washing, staining, and scanning were performed according to Affymetrix (Santa Clara, California, USA) protocols. Two copies of the entire HG-U95 chip set (HG-U95Av2, HG-U95B, HG-U95C, HG-U95D, and HG-U95E) were hybridized with each target. Absolute and comparative analyses were performed with Affymetrix Microarray Suite version 5 (MASv5) software, scaling all images to a value of 500. Results were further elaborated through replica analysis and statistical methods using software of our design (H. Muller, unpublished). Full details of microarray methods are available ("Supplementary Methods/Microarray Methods," ref. 12).

Semiquantitative PCR. First-strand cDNA synthesis was performed using the Superscript Microchip Kit (Gibco-BRL; Life Technologies Inc.), starting from $5 \mu \mathrm{g}$ of total RNA. To analyze patient samples, RNAs from five different individuals were pooled prior to cDNA synthesis. Each PCR reaction was performed using 1\% of the cDNA sample. For each pair of primers, the number of cycles required to detect a clear signal in the linear range was determined. The reactions were performed in triplicate and run on a $1.5 \%$ agarose gel; the GAPDH gene was used to normalize different samples. All sequences of primer pairs and specific PCR conditions for each gene can be found in "Supplementary Methods/Semi-Quantitative PCR Protocols" (12).

Real-time RT-PCR. Each $25 \mu \mathrm{l}$ reaction contained the following reagents: $0.5 \mu \mathrm{M}$ of each primer (sequences selected with the use of Primer Express software; PE Biosystems, Foster City, CA), $12.5 \mu \mathrm{l}$ of SYBR Green PCR Master MIX, 100 ng of template. Thermal Cycling Parameters were: 2 minutes at $50^{\circ} \mathrm{C}$, followed by 10 minutes 


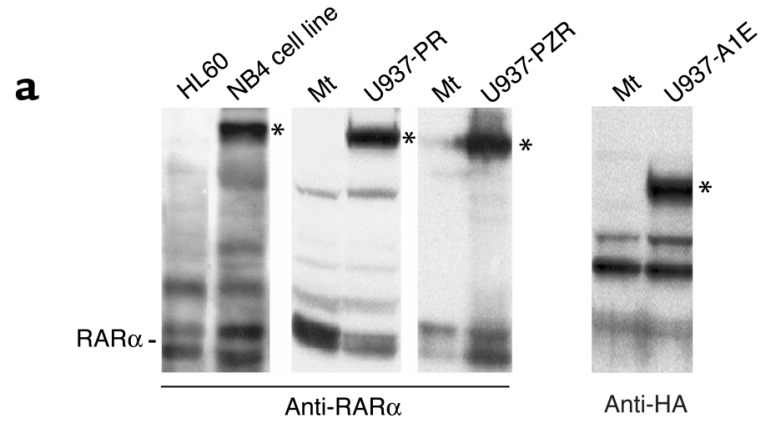

b

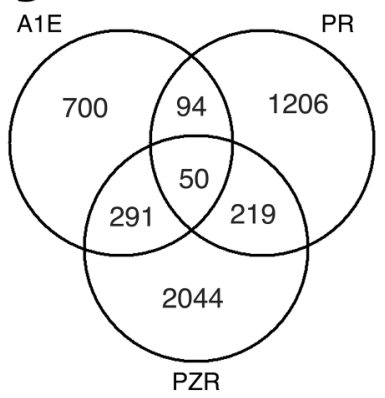

Induced expression

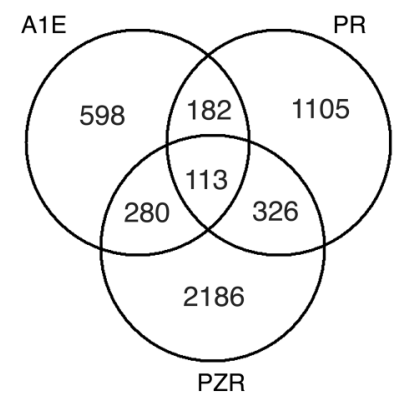

Decreased expression

Figure 1

(a) Western blot analysis of fusion-protein expression in the U937 clones used in this study. Asterisks indicate bands corresponding to fusion proteins. The left panel shows PML/RAR levels in the NB4 cell line, which are comparable to those of the U937 PML/RAR and U937 PLZF/RAR cell lines after 8 hours of treatment with $100 \mu \mathrm{M} \mathrm{ZnSO}$. Endogenous RAR $\alpha$ expression can be used to compare relative fusion-protein expression levels among different samples. Mt was the control. (b) Venn diagrams representing the overlaps among induced and repressed target genes. PR, PML/RAR; A1E, AML1/ETO; PZR, PLZF/RAR.

at $95^{\circ} \mathrm{C}$, followed by 40 cycles of 15 seconds at $95^{\circ} \mathrm{C}$, and 1 minute at $60^{\circ} \mathrm{C}$. Each sample was run in triplicate. The mean value of the replicates for each sample was calculated and expressed as cycle threshold $\left(C_{T}\right.$, cycle number at which each PCR reaction reaches a predetermined fluorescence threshold, set within the linear range of all reactions). The amount of gene expression was then calculated as the difference $\left(\Delta C_{T}\right)$ between the $C_{T}$ value of the sample for the target gene and the mean $C_{T}$ value of that sample for the endogenous control (GAPDH). Relative expression was calculated as the difference $\left(\Delta \Delta C_{T}\right)$ between the $\Delta C_{T}$ values of the test sample and of the control sample, $\mathrm{Mt}$, for each target gene. The relative quantitation value was expressed and shown as $2^{-\Delta \Delta C_{T}}$. All sequences of primer pairs can be found in "Supplementary Data/Supplementary Methods/Real Time RT PCR primers” (12).

Western blot analysis. U937 cell clones were harvested and lysed after 8, 12, 24, 36, and 48 hours of $\mathrm{Zn}^{+}$induction. Western blot analysis was performed using standard procedures. PML/RAR expression was evaluated using an anti-RAR $\alpha$ Ab (C-20 sc-551;

Santa Cruz Biotechnology Inc., Santa Cruz, California, USA), AML1/ETO expression was detected using an anti-HA Ab (Covance Research Products, Princeton, New Jersey, USA), Jagged 1 expression was detected using antiJagged1 Ab (C-20; Santa Cruz Biotechnology Inc.), and lamin expression was detected with an anti-lamin $\mathrm{B} \mathrm{Ab}$ (C-20 sc-6216; Santa Cruz Biotechnology Inc.).

Transactivation assay. HeLa cells were transfected with 200 ng of HES1 promoter-luciferase plasmid (pgl2-basic vector), $50 \mathrm{ng}$ of pCMV $\beta$ gal, and $200 \mathrm{ng}$ of either CMV promoter-driven PML/RAR (pcDNA3PML/RAR), AML1/ETO (pcDNA3AML1/ETO), or the constitutively active mutant intracellular domain of Notch (ICD Notch; cyto hN1pcAMP) using the Lipofectamine Reagent (Invitrogen). Forty-eight hours after transfection cells were lysed with lysis buffer $(25 \mathrm{mM}$ Tris- $\mathrm{HCl}$, pH 7.8, 2 mM DTT, 2 mM trans-1,2-diaminocyclohexane tetra-acetic acid (CDTA), 10\% glycerol, 1\% Triton $\mathrm{X}-100)$, and the luciferase activity was tested following standard protocols. Transfection efficiency was standardized with $\beta$-gal activity.

Comet assay. An alkaline single-cell gel electrophoresis (comet) assay was performed using the Trevigen comet assay kit (Trevigen Inc., Gaithersburg, Maryland, USA) according to the manufacturer's conditions. Control cells and cells expressing AML fusion proteins were treated with $200 \mu \mathrm{M}$ methyl methanesulfonate (MMS) for 2 hours at $37^{\circ} \mathrm{C}$, washed with ice-cold PBS, and finally rinsed with $\mathrm{RPMI} / 10 \% \mathrm{FBS}$. An alkaline comet assay was performed 2 and 6 hours after the end of MMS treatment. Samples were stained with supplied SYBR green dye, and the slides were viewed using a Leica DMRXA epifluorescence microscope. Images were analyzed with the NIH Image program (Bethesda, Maryland, USA). At least 50 randomly chosen cells were analyzed per sample. The percentage of remaining MMS damage was calculated by comparison with the total score $(100 \%)$ of initial DNA damage induced by MMS treatment ( $200 \mu \mathrm{M}, 2$ hours).

In vitro base excision repair assay. The procedures for preparation of plasmids have been described elsewhere (13). Briefly, pGEM3Zf (+) single-stranded DNA (Promega, Madison, Wisconsin, USA) was annealed with

Table 1

Microarray analysis of U937 cell lines expressing AML fusion proteins

\begin{tabular}{|c|c|c|c|c|c|c|}
\hline & \multicolumn{3}{|c|}{ Probe Sets } & \multicolumn{3}{|c|}{ Genes (UniGene Hs.159) } \\
\hline & Total & Induced & Decreased & Total & Induced & Decreased \\
\hline PR & 3707 & 1730 & 1977 & 3295 & 1569 & 1726 \\
\hline A1E & 2733 & 1373 & 1360 & 2308 & 1135 & 1173 \\
\hline PZR & 6939 & 3372 & 3567 & 5509 & 2604 & 2905 \\
\hline & \multicolumn{3}{|c|}{ Comparisons } & \multicolumn{3}{|c|}{ Opposite regulation by third fusion } \\
\hline Common to: & Total & Induced & Decreased & & Induced & Decreased \\
\hline ALL & 163 & 50 & 113 & & / & / \\
\hline $\mathrm{PR}$ and $\mathrm{A} 1 \mathrm{E}$ & 276 & 94 & 182 & & $28(30 \%)$ & $71(39 \%)$ \\
\hline $\mathrm{A} 1 \mathrm{E}$ and PZR & 571 & 291 & 280 & & 40 (14\%) & $34(12 \%)$ \\
\hline PR and PZR & 545 & 219 & 326 & & $23(11 \%)$ & 49 (15\%) \\
\hline
\end{tabular}

PR, PML/RAR; A1E, AML1/ETO; PZR, PLZF/RAR. 
a 22-mer oligonucleotide containing a single 8-oxoG in position 12 (pGEM 8-oxoG; TIB MOLBIOL, Genoa, Italy), thus generating a single 8-oxoG/cytosine base pair. Closed, circular double-stranded DNA was obtained by incubating with T4 DNA polymerase, gene 32 protein, and DNA ligase. Control pGEM T plasmids were prepared with an oligonucleotide carrying the normal base guanine in the same position. Plasmid substrate (300 ng) was incubated with $30 \mu \mathrm{g}$ of extract protein for the indicated times at $30^{\circ} \mathrm{C}$ in the presence of ${ }^{32} \mathrm{PdGTP}$. After the repair reaction, the DNA reaction product was purified, treated with the SmaI and Hind III restriction endonucleases, and separated by PAGE in the presence of $7 \mathrm{M}$ urea at $30 \mathrm{~mA}$. The length of the fragments was determined by $5^{\prime}$ end-labeled size markers.

\section{Results}

Identification of 1,555 genes deregulated by different AML fusion proteins and random validation of the microarray screening. We analyzed gene expression profiles of different U937 cell clones conditionally expressing PML/RAR, AML1/ETO, or PLZF/RAR. In these cells, the corresponding cDNAs are under the transcriptional control of the $\mathrm{Zn}$-inducible mouse metallothionein promoter. We used individual cell clones that showed comparable levels of fusion protein expression after $\mathrm{Zn}$ induction (Figure 1a). A U937 clone containing the empty cloning vector, $\mathrm{Mt}$, was used as control for each condition. For each clone we performed three independent experiments $(100 \mu \mathrm{M} \mathrm{Zn}$ for 8 hours) and then pooled the three RNAs. Biotinylated cRNA targets were synthesized from each RNA pool and hybridized to Affymetrix oligonucleotide chips (GeneChip HG-U95 set). Results were analyzed using MASv5 and further elaborated with proprietary software, as described in detail in "Microarray Methods" (12). GeneChip probe sets regulated by each fusion protein were clustered into nonredundant regulated genes following the UniGene release Hs.159 and EMBL and dbEST release 73 (Table 1). Sets of 3,295, 2,308, and 5,509 putative PML/RAR, AML1/ETO, and PLZF/RAR target
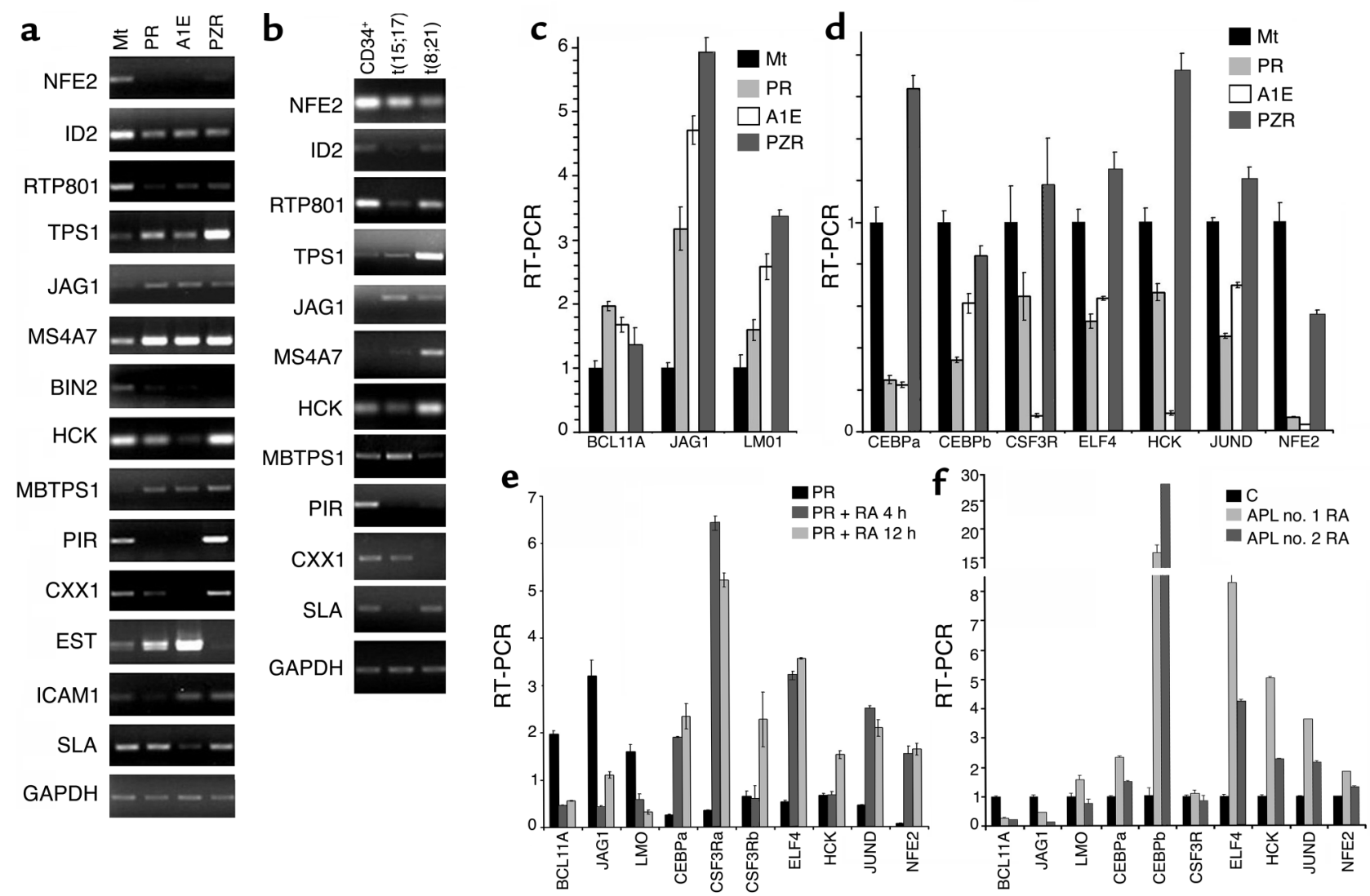

Figure 2

(a) Semiquantitative PCR analysis of 14 predicted targets. For each gene, the number of cycles required to detect a signal in the linear range was previously determined (see "Supplementary Methods," ref. 12). (b) Semiquantitative PCR analysis of AML blasts compared to CD34" normal precursors of 11 targets identified in the U937 system. Relative mRNA levels of induced target genes (c) and of repressed target genes (d) in U937 PML/RAR, U937 AML1/ETO or U937 PLZF/RAR cells assessed by real time RT-PCR. Mt was the control used in panels a, $\mathbf{c}$, and d. (e) Expression levels of common target genes in U937 PML/RAR cells before and after 4 or 8 hours of treatment with $10^{-6} \mathrm{M} \mathrm{RA}$. Values are calculated relatively to expression levels in Mt cells receiving the same treatment. (f) Expression levels of common target genes in blasts derived form two APL patients (APL no. 1 and APL no. 2) after 4 hours of in vitro treatment with 10-6 M RA. All values are shown as compared to the control (C); i.e., expression levels in blasts from the same individual, prior to RA treatment. All experiments shown in this figure were performed in triplicate. One representative experiment is shown for semiquantiative PCRs ( $\mathbf{a}$ and $\mathbf{b}$ ), whereas an average value of the three results was plotted for real time RT-PCR data (c-f). GAPDH gene expression was used to normalize all experiments. 
Table 2

Validation of GeneChip results in the U937 model system and in AML blasts

\begin{tabular}{lcccrrrrc} 
& \multicolumn{1}{c}{ GeneChip results } & \multicolumn{3}{c}{ Fold Change } & \multicolumn{2}{c}{ Concordance } \\
Gene & PR & A1E & PZR & PR & A1E & PZR & t(15;17) & $t(8 ; 21)$ \\
NFE2 & D & D & D & -4.3 & -6.3 & -3.4 & Yes & Yes \\
ID2 & D & D & D & -3.7 & -1.8 & -2.1 & Yes & \\
RTP801 & $\mathrm{D}$ & $\mathrm{D}$ & $\mathrm{D}$ & -18.8 & -5.4 & -2.0 & Yes & Yes \\
TPS1 & $\mathrm{I}$ & $\mathrm{I}$ & $\mathrm{I}$ & 3.0 & 1.8 & 23.6 & Yes & Yes \\
JAG1 & $\mathrm{I}$ & $\mathrm{I}$ & $\mathrm{I}$ & 2.7 & 2.2 & 1.9 & Yes & Yes \\
MS4A7 & $\mathrm{I}$ & $\mathrm{I}$ & $\mathrm{I}$ & 4.3 & 7.7 & 5.9 & & Yes \\
BIN2 & $\mathrm{D}$ & (D) & $\mathrm{D}$ & -2.6 & -0.1 & -2.0 & & \\
HCK & $\mathrm{D}$ & $\mathrm{D}$ & & -1.7 & -18.9 & 1.3 & Yes & No \\
MBTPS1 & $\mathrm{I}$ & (I) & $\mathrm{I}$ & 1.6 & -1.3 & 2.1 & Yes & No \\
PIR & $\mathrm{D}$ & $\mathrm{D}$ & $\mathrm{I}$ & -14.2 & -16.7 & 8.3 & Yes & Yes \\
CXX1 & $\mathrm{D}$ & $\mathrm{D}$ & $\mathrm{I}$ & -11.6 & -21.6 & 2.3 & Yes & Yes \\
EST & $\mathrm{I}$ & (I) & & 5.5 & 1.4 & -2.0 & & \\
ICAM1 & $\mathrm{D}$ & $\mathrm{I}$ & $(\mathrm{I})$ & -1.8 & 3.1 & 1.8 & & \\
SLA & & $\mathrm{D}$ & & -0.8 & -3.0 & -0.6 & No & No
\end{tabular}

GeneChip predictions are shown in the first three columns (D, decreased; I, increased). Letters between brackets indicate regulations detected by PCR analysis (Figure 2a) that were not predicted by GeneChip analysis. Fold changes predicted by Affymetrix results are shown. Yes and No indicate concordance or discordance of results obtained in AML blasts (Figure 2b) with results obtained in the U937 system. Mt was the control.

genes were obtained, respectively (Table 1). Cross comparisons of results identified 1,555 genes that are regulated in the same direction by at least two AML fusion proteins (AML common targets). Of these, 163 genes were predicted to be targets of all three fusion proteins, 276 were common to PML/RAR and AML1/ETO, 545 were common to PML/RAR and PLZF/RAR, and 571 were common to AML1/ETO and PLZF/RAR (Figure 1b). Of the 1,555 AML common targets, 245 (15\%) are regulated concordantly by two fusion proteins and in the opposite direction by the third fusion protein (Table 1). The complete results of the microarray study are available (12), including raw data, regulated probe sets, regulated genes, and common concordant targets.

It appears that some genes are regulated only by one fusion protein, while others are concordantly regulated by two or all three fusion proteins. While the first group of genes likely reflects specific biological properties of each fusion protein or different characteristics of the cell lines, the common genes might represent common functions targeted by AML fusion proteins and universal pathways involved in myeloid leukemogenesis. Therefore, we considered for further analysis all genes concordantly deregulated by at least two fusion proteins.

To determine the reliability of microarray data, we validated 14 putative targets by semiquantitative PCR and found full concordance between GeneChip predictions and expression levels in the U937 system (Figure 2a, Table 2). For a sizable fraction of the tested genes ( 4 of 14), more regulations were observed in the PCR assay than were expected from chip data, suggesting that the cohort of common targets may be larger than predicted.

We further investigated whether the U937 model system is predictive of patterns of gene regulation in AMLs by comparing levels of target gene expression in pools of RNA samples derived from control CD $34^{+}$hemopoietic precursor cells and $\mathrm{t}(15 ; 17)$ or $\mathrm{t}(8 ; 21)$ AML blasts, which harbor the PML/RAR and AML1/ETO fusion proteins, respectively. We observed a good degree of concordance of regulation in U937 PML/RAR cells and $\mathrm{t}(15 ; 17)$ blasts and in U937 AML1/ETO cells and t(8;21) blasts (9 of 11 and 7 of 11, respectively; Figure 2b, Table 2). The existence of genes with discordant regulations may reflect developmental rather than genetic differences between AML blasts (promyelocytes or M2 myeloblasts) and $\mathrm{CD} 34^{+}$control cells (hemopoietic precursors).

Functional classification of AML common target genes. We next attempted a functional classification of the 1,555 AML common targets by collecting annotations and keywords from various Web-based sources (NettAffx: http://www.affymetrix.com/analysis/index.affx; EST annotation machine: http://bio.ifom-firc.it/EST_ MACHINE; Stanford Online Universal Resource for Clones and ESTs: http://genome-www5.stanford.edu/ cgi-bin/SMD/source/sourceSearch; GeneCards: http:// genome-www.stanford.edu/genecards/; and LocusLink: http://www.ncbi.nlm.nih.gov/LocusLink/). Functional information was available for 876 genes. Initial clustering was then performed through the use of a keyword-clustering program (http://bio.ifom-firc.it/ KW_CLUST) and available literature (http://www. ncbi.nlm.nih.gov/PubMed). Four hundred forty-nine genes were classified within ten major functional categories, whereas for the remaining 427 genes the available information was insufficient (see Table 3 for categories; complete results can be viewed in "Functional Classification," ref. 12). We then analyzed individual members of each functional class with the aim of identifying functional pathways or transcriptional regulatory networks of potential relevance for the leukemic phenotype. Next, we report the results of this investigation for members of two classes (hemopoietic differentiation and DNA repair), for which concordance among physiological function, transcriptional regulation by AML fusion proteins, and contribution to the leukemic phenotype was immediately obvious and informative.

AML fusion proteins repress genes involved in commitment/differentiation control and induce genes involved in the maintenance of the stem cell phenotype. The group of AML common targets involved in the regulation of hemopoietic differentiation includes 15 genes, 3 of which are induced and 12 repressed by AML fusion proteins (Table 4). All are expressed in normal hemopoietic cells, although with different patterns: induced genes are predominantly expressed in HSC and/or early progenitors, whereas repressed genes prevail in differentiating progenitors and/or terminally differentiated hemopoietic cells.

Strikingly, induced genes (BCL11A, LMO1, and JAG1) have been implicated in the maintenance of the stem cell phenotype, mainly self-renewal of HSCs (14-16), while repressed genes control commitment decisions and maturation of HSCs toward the granulocytic (C/EBP family 
members, JUN family members, GFI1, CSF3R, STAT5A, HCK, ZNF1A1) (17-21), erythroid/megakaryocytic (NFE2) (22), or lymphoid (STAT5A, TCF3) $(23,24)$ lineages. Consistently, available genetic information indicates that induced genes contribute to leukemogenesis as overexpressed oncogenes, while the others have properties of tumor suppressors (Table 4). In the case of induced genes, null mutations in mice can lead to severe reduction of the HSC compartment (LMO1) (25), while enforced expression induces leukemias (LMO1) (15), expansion of HSCs (JAG1) (16), or in vitro transformation (BCL11A) (26). Notably, gain-of-function mutations of these genes have been identified in human or mouse hemopoietic tumors, including activation by retroviral insertion, gene amplification, chromosome translocations, or aberrant expression $(15,26)$. In the case of the repressed genes, instead, null mutations in mice lead to impaired differentiation of selected hemopoietic lineages (C/EBPs, JUNB, GFI1, CSF3R, STAT5A, NFE2, TCF3, and ZNF1A1), while their overexpression in HSCs or progenitors provokes terminal differentiation (C/EBPs and CSF3R) $(17,19,20,22$, 27-31). For some of these genes (C/EBP $\alpha, C S F 3 R, T C F 3$, and ZNF1A1), loss-of-function mutations have been identified in spontaneously occurring leukemias (29, 32-34). Repression of CEBP $\alpha$ expression in AML1/ETO-expressing cells has been described previously (35).

We then validated ten of the regulated genes by RT-PCR using RNA samples derived from U937 cells expressing the various AML fusion proteins (BCL11A, $J A G 1, L M O 1, C E B P \alpha, C E B P \beta, C S F 3 R, E L F 4, H C K, J U N D$, and NFE2). Results revealed concordance between GeneChip predictions and expression levels in the U937 system (Figure 2, $\mathrm{c}$ and $\mathrm{d}$ ). The seven downregulated genes (CEBP $\alpha, C E B P \beta, C S F 3 R, E L F 4, H C K, J U N D$, and NFE2) were repressed by PML/RAR and AML1/ETO, but not by PLZF/RAR (Figure 2d), suggesting different effects of the latter on the commitment/differentiation programs of hemopoietic precursors. Notably, this observation is in agreement with the results obtained in transgenic mice. In fact, while $P M L / R A R$ and $A M L 1 / E T O$ induce a blastlike acute leukemia in mice, $P L Z F / R A R$ transgenic animals show leukocytosis, increased percentage of mature myeloid cells, and increased myeloid/lymphoid ratio, and they develop a condition that resembles human chronic myeloid leukemia (7-10).

To test the relevance of these gene regulations for the leukemic phenotype, we measured their expression levels after 4 and 12 hours of RA treatment of U937PML/RAR cells, as compared with U937 control cells. RA treatment, in fact, reverts the differentiation block induced by PML/RAR in vitro and induces disease remission in the patients (3). Strikingly, for all genes tested, the deregulated expression caused by PML/RAR was counteracted by RA treatment, resulting either in expression levels that are similar to those found in control cells or to an inversion of the direction of the regulation (Figure 2e). Expression levels for the same genes were also measured in RNAs extracted from blasts of two APL patients before and after 4 hours of in vitro RA treatment (Figure 2f). All genes, with the exception of $L M O 1$ and CSF3R, were regulated by RA treatment in a direction that is opposite that determined by PML/RAR expression in U937 cells. These data reinforce the hypothesis that commonly regulated genes are relevant to the leukemia phenotype and are directly involved in the RA sensitivity mediated by PML/RAR. AML fusion proteins activate the Notch-signaling pathway. The predicted induction of JAG1 expression, taken together with the observation that other genes involved in Notch signaling are also AML common targets (LFNG, ADAM10, PARL, TLE2, and TLE3), prompted us to analyze in greater detail the status of $J A G 1$, for which

\section{Table 3}

Functional classification of AML-fusion protein target genes

Regulators of differentiation

Regulators of hemopoiesis

Notch signaling

No. of genes

DNA repair

BER pathway

Other mechanisms

Chromatin regulators

21

15

6

17

8

9

Cell cycle regulators

GO-G1 regulators

$\mathrm{S}$-phase regulators

G2-M regulators

Apoptosis regulators

Apoptosis inducers - mitochondrial

pathway (intrinsic pathway)

Apoptosis inducers - death

receptor pathway (extrinsic pathway)

Apoptosis inhibitors

Response to growth stimuli

Growth factors

Adaptor proteins

G-proteins

Kinases/phosphatses

$\mathrm{PI} 3 \mathrm{~K}$ pathway

Small GTP-binding proteins

TOR pathway

Protein modification

Cell structure and motility

Modulators of immune response

Tumor-induced immune response

MHCll processing

Cell adhesion

Metabolism

Energy metabolism

ATPases

Aminoacid metabolism

Nucleotide metabolism

Lipid metabolism

Complex lipid metabolism

Cofactors

Carbohydrate metabolism

Complex carbohydrate metabolism

Four hundred forty-nine common target genes were classified into 10 main functional categories. 38 genes could be classified in more than one category and are represented in a redundant manner. Detailed classification is available ("Functional Classification", ref. 12). 
Table 4

Common targets genes involved in the control of hemopoietic differentiation

\begin{tabular}{|c|c|c|c|c|c|c|c|c|}
\hline Gene & Expression pattern & $\begin{array}{l}\text { Effects of null } \\
\text { mutations }\end{array}$ & $\begin{array}{l}\text { Effects of } \\
\text { overexpression }\end{array}$ & $\begin{array}{l}\text { Involvement in } \\
\text { hemopoietic diseases }\end{array}$ & PR & A1E & PZR & References \\
\hline \multicolumn{9}{|c|}{ Repressed Genes } \\
\hline $\begin{array}{l}C / E B P \\
(\alpha \text { and } \beta)\end{array}$ & $\begin{array}{l}\text { Granulocyte, monocyte, } \\
\text { and eosinophil lineages: } \\
\text { myeloid precursors }(\alpha) \text {; } \\
\text { upregulated during } \\
\text { granulocytic differ- } \\
\text { entiation }(\beta)\end{array}$ & $\begin{array}{l}\text { Impaired granulocytic } \\
(\alpha) \text { and adipocyte }(\beta) \\
\text { differentiation; } \\
\text { Reduced B cell numbers; } \\
\text { defects in macrophage } \\
\text { activation }(\beta)\end{array}$ & $\begin{array}{l}\text { Growth arrest and } \\
\text { neutrophilic } \\
\text { differentiation of } \\
\text { HSCs }(\alpha \text { and } \beta)\end{array}$ & $\begin{array}{l}\text { Dominant negative } \\
\text { mutations in AML } \\
(\alpha) ; \text { rare mutations } \\
\text { CMLs }(\beta)\end{array}$ & $\mathrm{D}$ & $\mathrm{D}$ & & $(17,32)$ \\
\hline CSF3R & Granulocytic lineage & $\begin{array}{l}\text { Neutropenia and } \\
\text { impaired neutrophil } \\
\text { function }\end{array}$ & $\begin{array}{l}\text { Induction of neutrophilic } \\
\text { differentiation upon } \\
\text { G-CSF treatment }\end{array}$ & $\begin{array}{l}\text { Mutated in severe } \\
\text { congenital neutro- } \\
\text { penia and AML }\end{array}$ & $\mathrm{D}$ & $\mathrm{D}$ & & $(20,29)$ \\
\hline ELF4 & $\begin{array}{l}\text { Normal adult } \\
\text { hemopoietic tissue }\end{array}$ & NA & $\begin{array}{l}\text { Novel tumor suppressor } \\
\text { gene; suppression of } \\
\text { tumorigenesis of lung } \\
\text { adenocarcinoma A549 } \\
\text { cells both in vitro and } \\
\text { in vivo }\end{array}$ & NA & $\mathrm{D}$ & $\mathrm{D}$ & & (41) \\
\hline GFI1 & Mature granulocytes & $\begin{array}{l}\text { Impaired granulocytic } \\
\text { differentiation }\end{array}$ & NA & $\begin{array}{l}\text { Integration site for } \\
\text { Moloney murine } \\
\text { leukemia virus }\end{array}$ & $\mathrm{D}$ & & $\mathrm{D}$ & (19) \\
\hline HCK & $\begin{array}{l}\text { Mature granulocytes, } \\
\text { monocyte/macro- } \\
\text { phages, B cell } \\
\text { progenitors }\end{array}$ & $\begin{array}{l}\text { Modest myeloid } \\
\text { deficiency; double } \\
\text { knockout with other } \\
\text { Src-family kinases results } \\
\text { in extramedullary } \\
\text { hemopoiesis and } \\
\text { neutrophil defects }\end{array}$ & NA & NA & $\mathrm{D}$ & $\mathrm{D}$ & & $(20,21)$ \\
\hline $\begin{array}{l}\operatorname{JunB}, \\
\text { JunD }\end{array}$ & $\begin{array}{l}\text { Induced during } \\
\text { monocytic } \\
\text { differentiation }\end{array}$ & $\begin{array}{l}\text { Myeloproliferative } \\
\text { disorder (JunB) }\end{array}$ & $\begin{array}{l}\text { Growth suppression } \\
\text { (JunB); slower growth } \\
\text { and increase in \% of } \\
\text { cells in G0/G1 (JunD) }\end{array}$ & NA & $\mathrm{D}$ & $\mathrm{D}$ & D & $(18,28)$ \\
\hline NFE2 & $\begin{array}{l}\text { Differentiated erythroid, } \\
\text { megakaryocyte, and } \\
\text { mast cells }\end{array}$ & $\begin{array}{l}\text { Thrombocytopenia, } \\
\text { anemia }\end{array}$ & NA & $\begin{array}{l}\text { Mutated in the mouse } \\
\text { hypochromic micro- } \\
\text { cytic anemia (mk) }\end{array}$ & $\mathrm{D}$ & $\mathrm{D}$ & $\mathrm{D}$ & $(22)$ \\
\hline STAT5A & NA & $\begin{array}{l}\text { Multilineage peripheral } \\
\text { blood cytopenia and } \\
\text { reduced repopulating } \\
\text { activity }\end{array}$ & $\begin{array}{l}\text { Eosinophil differ- } \\
\text { entiation of primary } \\
\text { human hemopoietic } \\
\text { cells }\end{array}$ & $\begin{array}{l}\text { Retroviral integration } \\
\text { site in mouse pre-B } \\
\text { lymphomas }\end{array}$ & & $\mathrm{D}$ & $\mathrm{D}$ & $(30,43)$ \\
\hline TCF3 & & $\begin{array}{l}\text { Impaired B cell } \\
\text { differentiation; } \\
\text { Thymiclymphomas }\end{array}$ & $\begin{array}{l}\text { Ectopic expression } \\
\text { of E } 47 \text { or E12 promotes } \\
\text { the death of E2A- } \\
\text { deficient lymphomas }\end{array}$ & $\begin{array}{l}\text { Breakpoint site of } \\
\text { the } t(1 ; 19), t(17 ; 19) \\
\text { in ALLs }\end{array}$ & $\mathrm{D}$ & $\mathrm{D}$ & & $(14,31,44)$ \\
\hline ZNFN1A1 & $\begin{array}{l}\text { Expressed by all } \\
\text { hemopoietic cells }\end{array}$ & $\begin{array}{l}\text { Defects in the } \\
\text { lymphoidlineage }\end{array}$ & & $\begin{array}{l}\text { Leukemia and } \\
\text { lymphoma }\end{array}$ & $\mathrm{D}$ & $\mathrm{D}$ & $\mathrm{D}$ & $(21,34)$ \\
\hline \multicolumn{9}{|c|}{ Induced Genes } \\
\hline$B C L 11 A$ & $\begin{array}{l}\text { HSCs repressed } \\
\text { during myeloid } \\
\text { differentiation }\end{array}$ & NA & $\begin{array}{l}\text { Transformation of } \\
\text { NIH3T3 cells }\end{array}$ & \begin{tabular}{l} 
Integration site in \\
retrovirally induced \\
myeloid leukemias; \} $\\
{\text { involved in } \mathrm{t}(2 ; 14) \text { and }} \\
{2 \mathrm{p} 13 \text { amplification }} \\
{\text { in } \mathrm{NHL}}$ & I & 1 & & $(14,26)$ \\
\hline JAG1 & $\begin{array}{l}\text { HSCs; bone marrow } \\
\text { stromal cells, mature } \\
\text { mast cells, mega- } \\
\text { karyocytes }\end{array}$ & Severe vascular defects & $\begin{array}{l}\text { Increase in the forma- } \\
\text { tion of primitive } \\
\text { precursor cell } \\
\text { populations }\end{array}$ & NA & 1 & 1 & 1 & $(16,45,46)$ \\
\hline LMO1 & $\begin{array}{l}\text { Repressed during } \mathrm{T} \\
\text { cell development }\end{array}$ & $\begin{array}{l}\text { Knockout of SCL/TAL1 } \\
\text { regulatory complex } \\
\text { results in absence of } \\
\text { hemopoiesis in yolk sack }\end{array}$ & Leukemias & $\begin{array}{l}\text { Aberrantly expressed } \\
\text { in lymphoid leukemias }\end{array}$ & 1 & & 1 & $(15,47)$ \\
\hline
\end{tabular}
\end{tabular}

CML, chronic myeloid leukemia; ALL, acute lymphoblastic leukemia; NHL, non-Hodgkin lymphoma; NA, not available.

direct implication in leukemia is not available. Jagged 1 protein is expressed in bone marrow stromal cells and functions as a ligand for the Notch receptor, a critical factor in cell fate determination and maintenance of progenitor cells in many developmental systems (see ref.
36 for review). Notch-Jagged1 interactions cause an increase in the number of primitive precursor cells in normal murine bone marrow, characterized by high proliferative and multilineage potential and highreplating efficiency (16). Notch signaling is modulated 
at various levels, including (a) multiple ligands (Jagged/Serrate- or Delta-type ligands) and receptors (Notch1-Notch4); (b) glycosylation of the extracellular domain of Notch by Fringe proteins (in particular, LFNG inhibits Jagged1-mediated signaling through Notch1) (37); (c) cleavage of Notch receptors at the cell surface through ADAM family metalloproteases and presenilins; (d) processing of the intracellular domain and its translocation to the nucleus; and (e) interaction with transcriptional regulatory proteins and activation of target genes, including HES family genes.

Expression of either PML/RAR or AML1/ETO fusion proteins in U937 cells results in a significant increase of JAG1 mRNA (as opposed to a modest increase in JAG2 and no significant modification of DLL1) and protein (Figure 3, $a$ and $b$ ). LFNG mRNA expression (Figure 3c) is strongly repressed by both fusion proteins, suggesting that AML fusions activate the Notch pathway in AMLs preferentially through the Jagged 1 ligand. LFNG mRNA was strongly induced in APL blasts derived from two different patients (Figure 3d) after 4 hours of treatment in vitro with $10^{-6} \mathrm{M}$ RA.

Coexpression in HeLa cells (Figure 3e) or Phoenix cells (data not shown) of AML1/ETO or PML/RAR expression vectors with a Notch-responsive luciferase reporter gene (HES-Luc, which carries the luciferase gene under the control of the Notch-responsive HES1 promoter) resulted in a fivefold or tenfold increase of luciferase activity, respectively, comparable to that obtained by an activated ICD Notch 1 (eightfold increase). These results suggest that AML fusion protein expression results in specific activation of Notch signaling through the Jagged1 ligand.

We next performed RT-PCR to obtain a quantitative estimate of JAG1 and of LFNG expression in blasts derived from AML patients. In four of seven samples bearing $\mathrm{t}(8 ; 21)$ and in six of seven samples bearing $\mathrm{t}(15 ; 17)$, JAG1 mRNA levels were significantly higher than in $\mathrm{CD}_{3} 4^{+}$precursor cells, with average levels of induction of 9.8-fold and 2.8-fold, respectively (Figure 3f). LFNG expression in AML blasts was significantly decreased in six of six samples with $t(8 ; 21)$ and in five of five with $t(15 ; 17)$ samples, with average levels of repression of fivefold and 3.5-fold, respectively (Figure 3e). Finally, we investigated the level of expression of the Notch1 target gene HES1 in AML blasts and found increased HES1 mRNA levels in six of seven samples with $t(8 ; 21)$ and in seven of seven samples with $t(15 ; 17)$, with average levels of induction of 2.7-fold and 3.4-fold, respectively (Figure $3 \mathrm{f}$ ). Interestingly, overexpression of HES1 in vivo has been reported recently to induce lymphoid and myeloid alterations (38). It appears, therefore, that Notch signaling is constitutively activated in AML blasts. The activation of the Notch pathway by endogenously produced Jagged1 might provide a cell-autonomous mechanism of self-renewal, thus explaining the propensity of leukemic blasts to leave the bone marrow and invade the peripheral blood and other organs.

\section{Figure 3}

(a) mRNA levels of Notch ligands in Mt, U937PML/RAR and U937-AML1/ETO cells, assessed by real time RT-PCR. Relative expression levels are shown. (b) Western blot analysis of Jagged 1 protein expression in U937-PML/RAR and U937-AML1/ETO cells treated with $100 \mu \mathrm{M} \mathrm{ZnSO}_{4}$ for the indicated number of hours. Jagged 1 levels are shown in the top row, fusion protein expression in the middle row and lamin B expression in the bottom row. Jagged 1 expression in Mt cells was not modified by $\mathrm{ZnSO}_{4}$ treatment (data not shown). (c) Relative mRNA levels of LFNG in U937 PML/RAR and U937 AML1/ETO cells. Mt was the control in panels a and c. (d) LFNG mRNA levels dramatically increase after RA treatment in vitro of blasts from two different APL patients, as compared to the control (C); i.e., the same cells prior to treatment. (e) Expression of $\mathrm{PML} / \mathrm{RAR}$ or AML1/ETO in HeLa cells increases the activity of a Notch 1-responsive promoter. All values are plotted as relative fold activation. The black bar shows HES-Luc transactivation by an activated, intracellular domain of Notch 1 (ICD Notch1). (f) Relative expression of JAG1, LFNG and HES1 genes in blasts bearing the $t(15 ; 17)$ or the $t(8 ; 21)$ compared to $C D 34^{+}$cells, assayed by real time RT-PCR. The results shown are the average values obtained from cells derived from 7 different individuals for each condition. All RT-PCR data shown in this figure represents the average values of three independent measurements. GAPDH gene expression was used for normalization. Fold mRNAs are calculated from real time curves.

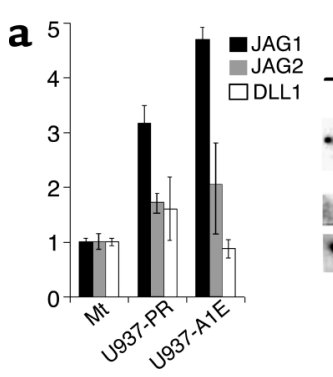

b

U937-PR U937-A1E $0 \quad 812243648 \quad 0 \quad 812243648$ $-0=00-m-5 A G 1$

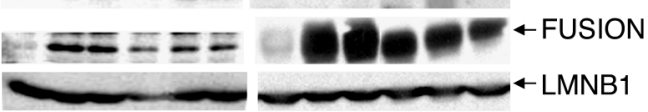
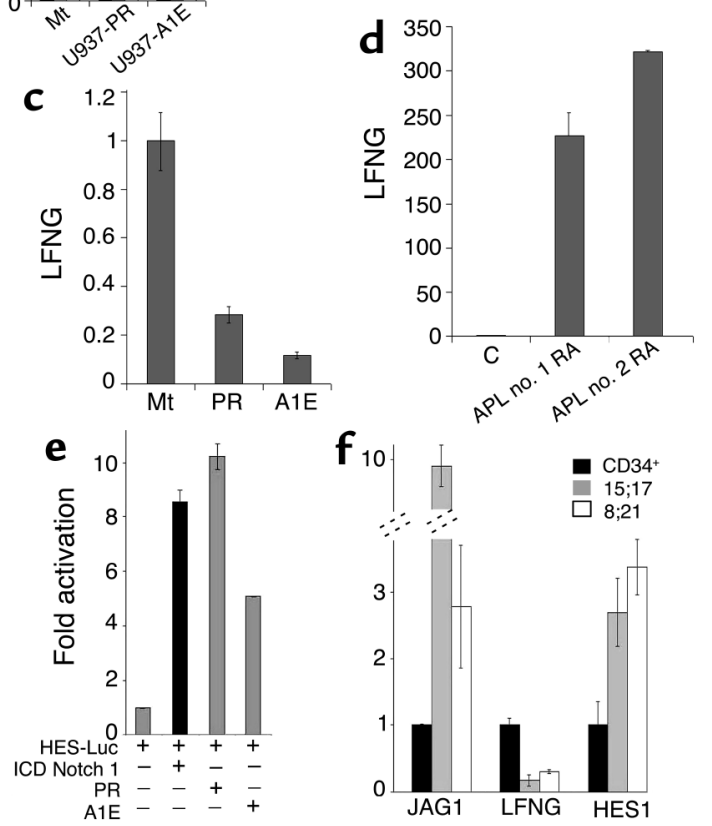
a
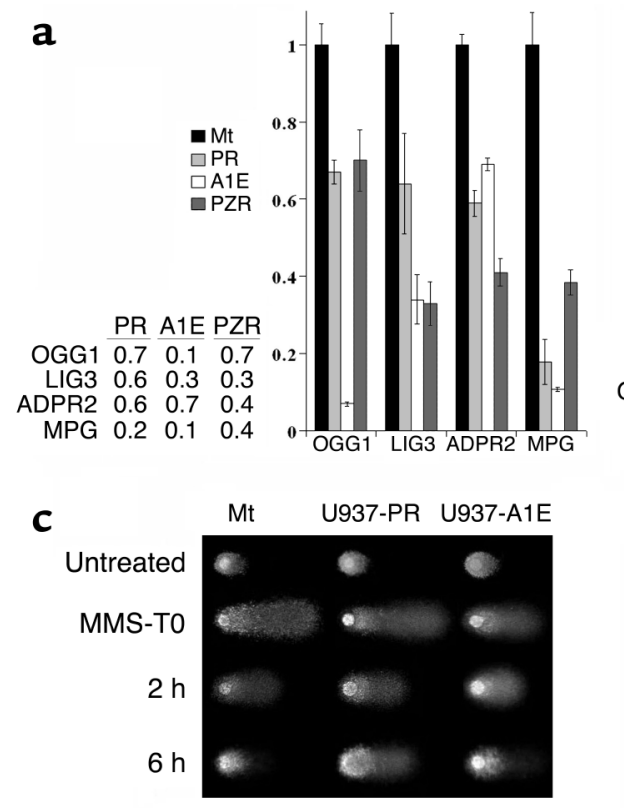

e

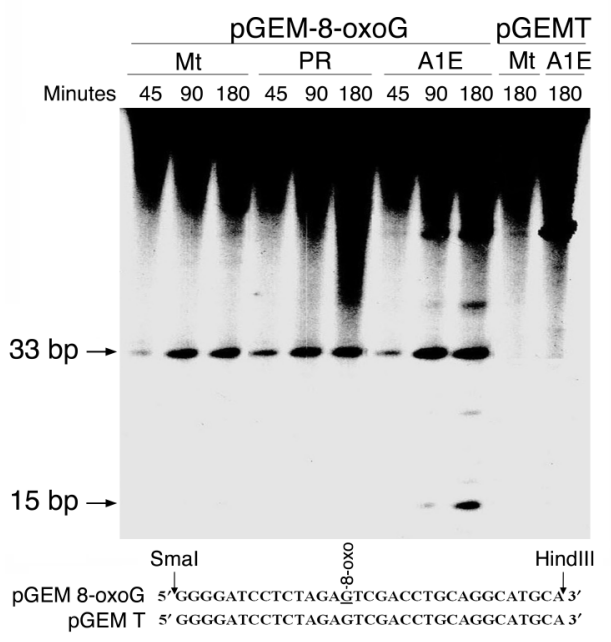

b

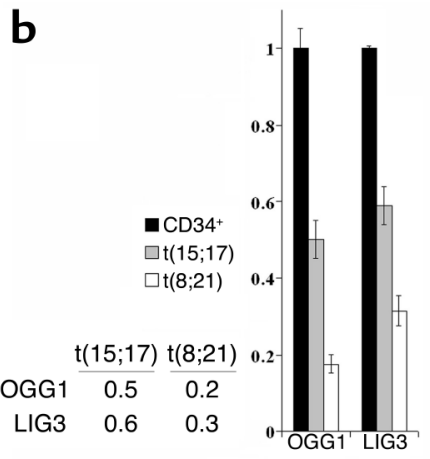

d

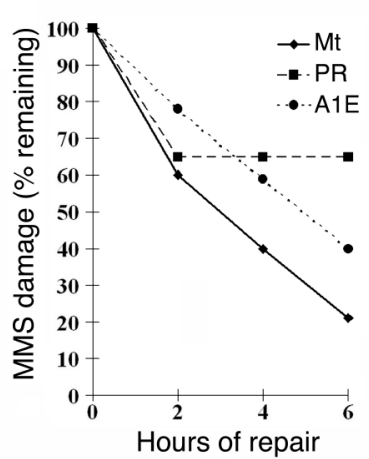

f

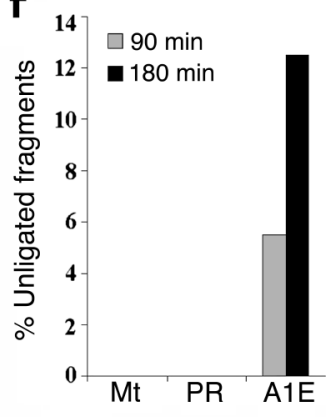

Figure 4

(a) The mRNA levels of OGG1, LIG3, ADPR2, and MPG in U937 PML/RAR, U937 AML1/ETO, or U937 PLZF/RAR cells, compared with Mt were assessed by real-time RT-PCR. Shown are average fold change values as calculated by real-time RT-PCR. (b) Relative expression of OGG1 and LIG3 genes in blasts bearing $t(15 ; 17)$ or $t(8 ; 21)$ compared with $\mathrm{CD} 34^{+}$cells, determined by real time RT-PCR. The results shown are the average values obtained from cells derived from seven different individuals for each condition. Shown are average fold change values as calculated by realtime RT-PCR. (c) Representative images were taken from alkaline comet assays of Mt, U937PML/RAR and U937-AML1/ETO cells before treatment (Untreated) immediately after treatment with $200 \mu \mathrm{M}$ MMS for two hours (T0), and 2 and 6 hours after removal of MMS. (d) Median relative tail moment of more than 50 cells for each data point, calculated by comparison with the total score $(100 \%)$ of initial DNA damage induced by MMS treatment. (e) In vitro BER assay. See text for detailed explanation. (f) Relative amount of unligated fragments. Data are the means of four independent experiments. For all experiments, both fusion protein-expressing U937 cells and control cells were treated with $100 \mu \mathrm{M} \mathrm{ZnSO}_{4}$ for 8 hours to allow for maximal fusion protein expression. Mt was the control for panels a, $\mathbf{c}-\mathbf{f}$.
AML fusion proteins induce a mutator phenotype. The second class of AML common targets that we report here are genes involved in diverse mechanisms of DNA repair. This class includes 17 genes that take part in various pathways. Strikingly, eight genes are involved in base excision repair (BER) (ADPRTL2, FEN1, OGG1, $M P G, L I G 3, P O L B, P O L D 2$, and POLD3). Null mutations of these genes in mice are often incompatible with life, and when they are not, they generally result in an increased sensitivity to mutagens and/or an accumulation of DNA damage $(39,40)$ (Table 5$)$. All these genes are downregulated by AML fusion proteins, with the exception of $P O L B$, which is induced (Table 5). Interestingly, overexpression of $P O L B$ in human cell lines results in increased spontaneous mutagenesis (39).

Validation of some of these regulations in the U937 cell system (ADPRTL2, OGG1, MPG, and LIG3) or in AML patient blasts (OGG1 and LIG3) confirmed the GeneChip predictions (Figure 4, a and b). Therefore, we tested U937 cells expressing PML/RAR or AML1/ETO for DNA repair efficiency using two approaches. First, we analyzed by single-cell gel electrophoresis (COMET assay) the ability of U937 cells expressing PML/RAR or AML1/ETO to repair DNA damage induced by MMS (which causes single-strand DNA breaks). In this assay, damaged DNA is visualized by gel electrophoresis through the appearance of low-molecular-weight fragments or comets. A significant reduction in DNA repair was observed in PML/RAR cells 6 hours after interruption of MMS treatment, whereas AML1/ETO cells showed a more modest increase in comet tail moment when compared with control cells (Figure 4, c and d).

In a second approach, we measured the ability of lysates from U937 cells to repair 8-oxoG, one of the most frequent endogenous DNA lesions, usually repaired by the BER pathway. Repair replication experiments were conducted using cell extracts and DNA plasmid substrates that harbor a single 8-oxoG (pGEM 8-oxoG) located centrally (fifteenth nucleotide) within a SmaI/Hind III 33-mer restriction fragment (Figure 4e, bottom). DNA plasmid substrates harboring a single 8-oxoG within a SmaI/HindIII 33-mer restriction fragment were incubat- 
ed with the various cell extracts recovered after the BER reaction, treated with appropriate restriction endonucleases, and separated by gel electrophoresis. Whereas the presence of radiolabeled 33-mer fragments reflects completed repair events, the presence of radiolabeled 15- to 32-mer fragments indicates the persistence of unligated intermediates of BER. In the case of control Mt cells and cells expressing PML/RAR (Figure 4e), all repair events were efficiently completed at all incubation times. In contrast, cells expressing AML1/ETO displayed a ligation defect, with an average of $5.5 \%$ and $12.5 \%$ repair patches remaining unligated after 1.5 and 3 hours of incubation time, respectively (Figure 4, e and f).

In conclusion, the two assays unraveled partial DNA repair defects in both PML/RAR- and AML1/ETOexpressing cells, suggesting that the specific molecular mechanisms primarily targeted by the two fusion proteins may be different, but that, in both cases, they could provoke accumulation of DNA mutations or lesions.

\section{Discussion}

We have investigated the transcriptional targets of three AML-associated fusion proteins and demonstrated that, despite molecular heterogeneity, they have a common set of target genes seemingly relevant for transformation, implying that leukemogenesis involves deregulation of common molecular mechanisms. Discovering these pathways may allow identification of common targets for antileukemic strategies, bypassing the great molecular heterogeneity of leukemias in humans. Furthermore, we showed that functionally related genes are coherently regulated by AML fusion proteins. Regardless of their relevance to the transformation process, these peculiar transcriptional phenotypes suggest the existence of hierarchical mechanisms of transcriptional regulation for groups of functionally related target genes. While genes that act as master transcriptional regulators of differentiation have been hypothesized previously, this is unexpected for DNA repair genes. Finally, our results provide evidence for the existence of novel biological activities of AML fusion proteins, which might be relevant for the leukemogenic process (i.e., the induction of a stem cell phenotype and the induction of a mutator phenotype).

The induction of genes involved in the maintenance of the stem cell phenotype might account for the modest effects of AML-fusion protein expression on hemopoietic development during the preleukemic phase of transgenic mice (7-10). Ligand activation of Notch in murine marrow precursors slightly (twofold to threefold) increases the generation or maintenance of very early precursors or stem cells, while it does not affect differentiation of mature myeloid cells (16). AML fusion proteins might stimulate the machinery for self-renewing cell divisions of target cells, therefore provoking a slight expansion of the stem cell compartment. An increased pool of stem cells might compensate the phenotypic consequences of the simultaneous repression of differentiation/commitment genes, creating a preleukemic hemopoiesis with minor or no morphological abnormalities.

The expansion of the stem cell compartment by AML fusion proteins might increase, per se, the likelihood of incoming mutations. AML fusion proteins, however, repress the expression of several DNA repair genes, suggesting that they induce genomic instability. Indeed, genetic alterations of various DNA repair genes are associated with cancer predisposition in humans (40). Most frequently they involve genes of the homologous recombination and double-strand break-repair pathways and are associated with multiple chromosome aberrations. Leukemias have a low frequency of complex cytogenetic aberrations, and AML fusion proteins downregulate mainly genes of the BER pathway. BER deals with small chemical alterations of bases and is, therefore, particularly relevant for preventing mutagenesis. We propose, therefore, that the inhibitory effect of fusion proteins on BER is responsible for a specific type of genetic instability in leukemias that causes the accumulation of DNA mutations and progression of the leukemic phenotype.

Table 5

Common targets genes involved in DNA repair - BER pathway

\begin{tabular}{|c|c|c|c|c|c|c|c|}
\hline Gene & Effects of null mutations & Effects of overexpression & Cancer predisposition & PR & A1E & PZR & Reference \\
\hline $\begin{array}{l}\text { ADPRTL2 } \\
(\text { PARP-2) }\end{array}$ & $\begin{array}{l}\text { Delay in resealing } \\
\text { DNA strand breaks }\end{array}$ & $\begin{array}{l}\text { No protection against the effects of } \\
\text { DNA-damaging agents; can result } \\
\text { in ATP depletion and cell death }\end{array}$ & NA & $\mathrm{D}$ & & $\mathrm{D}$ & $(48)$ \\
\hline FEN1 & $\begin{array}{l}\text { Lethal in homozygous null animals; } \\
\text { haploinsufficiency leads to } \\
\text { rapid tumor progression }\end{array}$ & NA & NA & $\mathrm{D}$ & $\mathrm{D}$ & & $(49)$ \\
\hline LIG3 & $\begin{array}{l}\text { Defect in rejoining of radiation-induced } \\
\text { DNA single- and double-strand breaks }\end{array}$ & NA & NA & $\mathrm{D}$ & & $\mathrm{D}$ & $(50)$ \\
\hline OGG1 & $\begin{array}{l}\text { Accumulation of oxidative DNA base } \\
\text { damage restricted to slowly proliferating } \\
\text { tissues with high oxygen metabolism }\end{array}$ & $\begin{array}{l}\text { Increased repair rate } \\
\text { of 8-oxoG residues }\end{array}$ & Carcinomas & $\mathrm{D}$ & $\mathrm{D}$ & $\mathrm{D}$ & (39) \\
\hline$P O L B$ & Lethal & $\begin{array}{l}\text { Increased spontaneous mutagenesis } \\
\text { and high mutagenic tolerance }\end{array}$ & Breast cancer & 1 & 1 & & (39) \\
\hline POLD2 & $\begin{array}{l}\text { Cancer susceptibility } \\
\text { (by homology to POLD1) }\end{array}$ & NA & NA & & $\mathrm{D}$ & $\mathrm{D}$ & $(51)$ \\
\hline POLD3 & $\begin{array}{l}\text { Cancer susceptibility } \\
\text { (by homology to POLD1) }\end{array}$ & NA & NA & & $\mathrm{D}$ & $\mathrm{D}$ & $(51)$ \\
\hline
\end{tabular}




\section{Acknowledgments}

The authors are grateful to Clara Nervi, Francesco LoCoco, and Antonio Tabilio for patient samples and $\mathrm{CD} 34^{+}$cells and to S. Minucci and F. McBlane for critical reviewing of the manuscript. This work is supported by grants from Associazione Italiana per la Ricerca sul Cancro to M. Alcalay, P.P. Di Fiore, G. Frosina, and P.G. Pelicci; from the European Community to P.G. Pelicci; and from Compagnia di S. Paolo to G. Frosina. N. Meani was supported by a fellowship from Fondazione Italiana per la Ricerca sul Cancro.

1. Mitelman, F. 1994. Catalogue of chromosome aberrations in Cancer. WileyLiss. New York, New York, USA. 4252 pp.

2. Look, A.T. 1997. Oncogenic transcription factors in the human acute leukemias. Science. 278:1059-1064.

3. Alcalay, M., et al. 2001. Common themes in the pathogenesis of acute myeloid leukemia. Oncogene. 20:5680-5694.

4. Grignani, F., et al. 1993. The acute promyelocytic leukemia-specific PML-RAR alpha fusion protein inhibits differentiation and promotes survival of myeloid precursor cells. Cell. 74:423-431.

5. Gelmetti, V., et al. 1998. Aberrant recruitment of the nuclear receptor corepressor-histone deacetylase complex by the acute myeloid leukemia fusion partner ETO. Mol. Cell Biol. 18:7185-7191.

6. Ruthardt, M., et al. 1997. Opposite effects of the acute promyelocytic leukemia PML-retinoic acid receptor alpha (RAR alpha) and PLZF-RAR alpha fusion proteins on retinoic acid signalling. Mol. Cell Biol. 17:4859-4869.

7. He, L.Z., et al. 1998. Distinct interactions of PML-RARalpha and PLZFRARalpha with co-repressors determine differential responses to RA in APL. Nat. Genet. 18:126-135.

8. Brown, D., et al. 1997. A PMLRARalpha transgene initiates murine acute promyelocytic leukemia. Proc. Natl. Acad. Sci. U. S. A. 94:2551-2556.

9. Higuchi, M., et al. 2002. Expression of a conditional AML1-ETO oncogene bypasses embryonic lethality and establishes a murine model of human $\mathrm{t}(8 ; 21)$ acute myeloid leukemia. Cancer Cell. 1:63-74.

10. Grisolano, J.L., Wesselschmidt, R.L., Pelicci, P.G., and Ley, T.J. 1997. Altered myeloid development and acute leukemia in transgenic mice expressing PML-RAR alpha under control of cathepsin G regulatory sequences. Blood. 89:376-387.

11. Schoch, C., et al. 2002. Acute myeloid leukemias with reciprocal rearrangements can be distinguished by specific gene expression profiles. Proc. Natl. Acad. Sci. U. S. A. 99:10008-10013.

12. Alcalay, M., et al. 2003. Supplementary data. http://bio.ifom-firc.it/ User/Suppl/.

13. Frosina, G., Cappelli, E., Fortini, P., and Dogliotti, E. 1999. In vitro base excision repair assay using mammalian cell extracts. Methods Mol. Biol. 113:301-315.

14. Saiki, Y., Yamazaki, Y., Yoshida, M., Katoh, O., and Nakamura, T. 2000. Human EVI9, a homologue of the mouse myeloid leukemia gene, is expressed in the hematopoietic progenitors and down-regulated during myeloid differentiation of HL60 cells. Genomics. 70:387-391.

15. Chervinsky, D.S., et al. 1999. Disordered T-cell development and T-cell malignancies in SCL LMO1 double-transgenic mice: parallels with E2Adeficient mice. Mol. Cell Biol. 19:5025-5035.

16. Varnum-Finney, B., et al. 1998. The Notch ligand, Jagged-1, influences the development of primitive hematopoietic precursor cells. Blood. 91:4084-4091.

17. Radomska, H.S., et al. 1998. CCAAT/enhancer binding protein alpha is a regulatory switch sufficient for induction of granulocytic development from bipotential myeloid progenitors. Mol. Cell Biol. 18:4301-4314.

18. Lord, K.A., Abdollahi, A., Hoffman-Liebermann, B., and Liebermann, D.A. 1993. Proto-oncogenes of the fos/jun family of transcription factors are positive regulators of myeloid differentiation. Mol. Cell Biol. 13:841-851.

19. Karsunky, H., et al. 2002. Inflammatory reactions and severe neutropenia in mice lacking the transcriptional repressor Gfi1. Nat. Genet. 30:295-300.

20. Ward, A.C., Loeb, D.M., Soede-Bobok, A.A., Touw, I.P., and Friedman, A.D. 2000. Regulation of granulopoiesis by transcription factors and cytokine signals. Lenkemia. 14:973-990.

21. Dumortier, A., Kirstetter, P., Kastner, P., and Chan, S. 2003. Ikaros regulates neutrophil differentiation. Blood. 101:2219-2226.

22. Li, Y.J., et al. 2001. p45(NFE2) is a negative regulator of erythroid proliferation which contributes to the progression of Friend virus-induced erythroleukemias. Mol. Cell Biol. 21:73-80.
23. Bain, G., et al. 1994. E2A proteins are required for proper B cell development and initiation of immunoglobulin gene rearrangements. Cell. 79:885-892.

24. Sexl, V., et al. 2000. Stat5a/b contribute to interleukin 7-induced B-cell precursor expansion, but abl- and bcr/abl-induced transformation are independent of stat5. Blood. 96:2277-2283.

25. Zhu, J., and Emerson, S.G. 2002. Hematopoietic cytokines, transcription factors and lineage commitment. Oncogene. 21:3295-3313.

26. Satterwhite, E., et al. 2001. The BCL11 gene family: involvement of BCL11A in lymphoid malignancies. Blood. 98:3413-3420.

27. Zhang, D.E., et al. 1997. Absence of granulocyte colony-stimulating factor signaling and neutrophil development in CCAAT enhancer binding protein alpha-deficient mice. Proc. Natl. Acad. Sci. U. S. A. 94:569-574.

28. Passegue, E., Jochum, W., Schorpp-Kistner, M., Mohle-Steinlein, U., and Wagner, E.F. 2001. Chronic myeloid leukemia with increased granulocyte progenitors in mice lacking junB expression in the myeloid lineage. Cell. 104:21-32.

29. Hermans, M.H., et al. 1998. Perturbed granulopoiesis in mice with a targeted mutation in the granulocyte colony-stimulating factor receptor gene associated with severe chronic neutropenia. Blood. 92:32-39.

30. Buitenhuis, M., Baltus, B., Lammers, J.W., Coffer, P.J., and Koenderman, L. 2002. Signal transducer and activator of transcription 5a (STAT5a) is required for eosinophil differentiation of human cord blood derived CD34+ cells. Blood. 101:134-142.

31. Engel, I., and Murre, C. 1999. Ectopic expression of E47 or E12 promotes the death of E2A-deficient lymphomas. Proc. Natl. Acad. Sci. U. S. A 96:996-1001.

32. Pabst, T., et al. 2001. Dominant-negative mutations of CEBPA, encoding CCAAT/enhancer binding protein-alpha (C/EBPalpha), in acute myeloid leukemia. Nat. Genet. 27:263-270.

33. Aspland, S.E., Bendall, H.H., and Murre, C. 2001. The role of E2A-PBX1 in leukemogenesis. Oncogene. 20:5708-5717.

34. Winandy, S., Wu, P., and Georgopoulos, K. 1995. A dominant mutation in the Ikaros gene leads to rapid development of leukemia and lymphoma. Cell. 83:289-299.

35. Pabst, T., et al. 2001. AML1-ETO downregulates the granulocytic differentiation factor C/EBPalpha in $\mathrm{t}(8 ; 21)$ myeloid leukemia. Nat. Med. 7:444-451.

36. Kopan, R. 2002. Notch: a membrane-bound transcription factor. J. Cell Sci. 115:1095-1097.

37. Moloney, D.J., et al. 2000. Fringe is a glycosyltransferase that modifies Notch. Nature. 406:369-375

38. Kawamata, S., Du, C., Li, K., and Lavau, C. 2002. Overexpression of the Notch target genes Hes in vivo induces lymphoid and myeloid alterations. Oncogene. 21:3855-3863.

39. Frosina, G. 2000. Overexpression of enzymes that repair endogenous damage to DNA. Eur. J. Biochem. 267:2135-2149.

40. Hoeijmakers, J.H. 2001. Genome maintenance mechanisms for preventing cancer. Nature. 411:366-374.

41. Seki, Y., et al. 2002. The ETS transcription factor MEF is a candidate tumor suppressor gene on the X chromosome. Cancer Res. 62:6579-6586.

42. English, B.K. 1996. Expression of the activated (Y501-F501) hck tyrosine kinase in $32 \mathrm{Dcl} 3$ myeloid cells prolongs survival in the absence of IL-3 and blocks granulocytic differentiation in response to G-CSF. J. Lenkoc. Biol. 60:667-673.

43. Ilaria, R.L., Jr., Hawley, R.G., and Van Etten, R.A. 1999. Dominant negative mutants implicate STAT5 in myeloid cell proliferation and neutrophil differentiation. Blood. 93:4154-4166.

44. Yan, W., et al. 1997. High incidence of T-cell tumors in E2A-null mice and E2A/Id1 double- knockout mice. Mol. Cell Biol. 17:7317-7327.

45. Tanaka, J., Iwata, M., Graf, L., Guest, I., and Torok-Storb, B. 1999. Stromal inhibition of myeloid differentiation. A possible role for hJagged1. Ann. N. Y. Acad. Sci. 872:171-172; discussion 172-175.

46. Karanu, F.N., et al. 2000. The notch ligand jagged-1 represents a novel growth factor of human hematopoietic stem cells. J. Exp. Med. 192:1365-1372.

47. Valge-Archer, V., Forster, A., and Rabbitts, T.H. 1998. The LMO1 and LDB1 proteins interact in human $\mathrm{T}$ cell acute leukaemia with the chromosomal translocation $\mathrm{t}(11 ; 14)(\mathrm{p} 15 ; \mathrm{q} 11)$. Oncogene. 17:3199-3202.

48. Schreiber, V., et al. 2002. Poly(ADP-ribose) polymerase-2 (PARP-2) is required for efficient base excision DNA repair in association with PARP1 and XRCC1. J. Biol. Chem. 277:23028-23036.

49. Kucherlapati, M., et al. 2002. Haploinsufficiency of Flap endonuclease (Fen1) leads to rapid tumor progression. Proc. Natl. Acad. Sci. U. S. A 99:9924-9929.

50. Nocentini, S. 1999. Rejoining kinetics of DNA single- and double-strand breaks in normal and DNA ligase-deficient cells after exposure to ultraviolet $\mathrm{C}$ and gamma radiation: an evaluation of ligating activities involved in different DNA repair processes. Radiat. Res. 151:423-432.

51. Goldsby, R.E., et al. 2001. Defective DNA polymerase-delta proofreading causes cancer susceptibility in mice. Nat. Med. 7:638-639. 